\title{
Risk factors associated with taeniasis-cysticercosis in Lagamar, Minas Gerais State, Brazil
}

\author{
Fatores de risco relacionados com teníase e cisticercose em \\ Lagamar, Estado de Minas Gerais, Brasil
}

\author{
Mario León Silva-Vergara, Aluízio Prata, Horácio Velloso Silveira Netto, Cláudio \\ de Oliveira Vieira, João Henrique Castro, Luciane G iroto Micheletti, \\ Arturo Santana 0 taño and João Franquini Júnior
}

\begin{abstract}
An epidemiological survey was carried out in 3,344 people of an urban town in Lagamar, Minas Gerais, Brazil - during 1992-1993, to evaluate the main risk factors related to taeniasis and cysticercosis. A total number of 875 (78.9\%) houses were visited and 1080 (32.3\%) subjects were clinically examined. Poor sanitary conditions were positively associated with former history of taeniasis or seizures in households $(p<0.05)$. It was remarkable the positive relationship between taeniasis and seizures when households were questioned and subjects were clinically evaluated $(p<0.05)$. The relative risk of seizures was 2.3 between households and 1.7 for individuals clinically examined respectively. The breeding of swine nearby and the chronic carriers of taeniasis are determinant factors in the maintenance of the epidemiological link between taeniasis and cysticercosis in endemic areas.
\end{abstract}

Key-words: Taeniasis. Cysticercosis. Seizures. Swine.

Resumo Foi realizado inquérito epidemiológico em 3344 indivíduos da área urbana de Lagamar, Minas Gerais, Brasil, durante 1992-1993 para avaliar os principais fatores de risco relacionados com teníase e cisticercose. Foram visitadas 875 (78,9\%) casas e examinados clinicamente 1080 (32,3\%) indivíduos. As condições sanitárias deficientes estiveram associadas estatisticamente com história anterior ou atual de teníase ou de convulsões entre os membros de cada família $(p<0,05)$. A correlação entre teniase e convulsões foi evidenciada tanto no inquérito domiciliar como durante a avaliação clínica dos indivíduos $(p<0,0001)$. O risco relativo de convulsões foi de 2,3 entre os moradores entrevistados no domicílio e 1,7 entre os indivíduos que compareceram para exame clínico, respectivamente. A criação de suínos no peridomicílio e os portadores crônicos de teníase são fatores determinantes na perpetuação do elo epidemiológico teníase-cisticercose nas áreas endêmicas.

Palavras-chaves: Teníase. Cisticercose. Convulsões. Suínos.

Disciplina de Doenças Infecciosas e Parasitárias da Faculdade de Medicina do Triângulo Mineiro e Fundação Nacional de Saúde. Uberaba, MG, Brasil.

Endereço para correspondência: Dr. Mario León Silva-Vergara. Medicina Tropical/FMTM. Caixa Postal 118, 38001-970 Uberaba, Minas Gerais, Brasil. Fax: (034) 318-5287.

Recebido para publicação em 26/06/97. 
Taeniasis and cysticercosis caused by Taenia solium is widespread in Latin America, Asia, Africa and some countries of Eastern Europe where the standard of living and sanitary conditions are poor 521.

The maintenance of an endemic situation in these areas is due to the breeding of swine under primary procedures. Its close relation with people facilitates the intake of excrement of those chronic carriers of Taenia $s p$ and the development of Cysticercus cellulosae into swine's tissues, specially muscles. People eat pork from several different kinds of preparation depending on the local, cultural and gastronomic habits. The intake of raw or rare meat is a common practice among inhabitants in the endemic areas for taeniasis and cysticercosis and is the main risk factor for acquiring this parasitosis2 5 .

Human cysticercosis results from the inadvertent intake of Taenia solium eggs found on the hands of chronic carriers and probably in foods and in contaminated water. After ingestion, the eggs are digested by gastric enzymatic process with the delivering of embryos or hexacants that penetrate into the systemic circulation and are mainly lodged into the striated muscle, brain, cellular subcutaneous tissue and eyes2 361117 . Cysticercosis derived of cellulosae or racemosus form of cystercus is one of the parasitic diseases that frequently invade the central nervous system (CNS) and it can be the etiologic explanation at $50 \%$ of seizure ethiology in endemic areas specially when they begin during adult life6 10131823 .

Despite great interest shown by scientists in the countries where this parasitosis is a public health problem and the outstanding amount of scientific contributions related to this topic considering its several aspects, few attempts have been made with the purpose of controlling it. Such attempts would demand radical changes in the living standards of the population of such areas.

In recent years a remarkable interest has arisen to evaluate the main risk factors related to taeniasis and cysticercosis, trying to identify the interaction among them. This way the epidemiological link could be broken4 781213192026 . Working in endemic area, we decided to evaluate some of these epidemiological factors.

\section{MATERIALS AND METHODS}

The epidemiological survey related to taeniasis and cysticercosis was carried out in the city of
Lagamar, State of Minas Gerais, Brazil during 1992-1993. Its economy is based mainly in agriculture, cattle and swine activities. The absence of a local slaughterhouse results in butchering in clandestine conditions and meat is sold and consumed without any sanitary control. Also the breeding of pigs in the urban area is characterized by poor maintenance conditions.

One epidemiological questionaire was elaborated to register aspects related to: household identification, address, sanitary facilities, water sources, eating habits, waste disposal sites, livestock and pet population mainly pigs, giving special emphasis on the current husbandry conditions, prior husbandry in rural area, knowledge about the tapeworm, prior history of seizures or passed proglottids or tapeworms in any household. For this survey all houses were visited and population registered.

The clinical examination was carried out in the local health unit and individuals were invited for coming there voluntary. Other records were reviewed to characterize the individual information about eating habits mainly related to pork or derived products, vegetables, knowledge of tapeworms and proglottids and prior history of seizures, neurological and mental disordes or presence of subcutaneous nodules. Not sampling was performed in this clinical survey.

Coproparasitologic studies were carried out using the Hoffmann pons, Janer, Kato Katz and Baermann Moraes tecnics.

Some epidemiological aspects and neurological evaluation of this population were previously published24 25.

The statistical analysis was made using qui square $\chi^{2}$ and Fisher method when indicated and the level of statistical significance was $5 \%$.

\section{RESULTS}

Out of 1109 houses registered during the survey, $875(78.9 \%)$ were inhabited and the others consisted of public buildings, shops or had no residentes at the time. A total of 3,344 inhabitants were found, being $1,635(48,9 \%)$ males and $1,709(51.1 \%)$ females. The number of rooms in a house varied from one to fifteen. The average of inhabitants per house was four. The water supply was provided by Municipal Services in 860 (98.3\%) houses, the waste disposal was made appropriately in $353(40,3 \%)$ houses through public services and the 
presence of sanitary facilities was confirmed in $726(83 \%)$ houses.

Pet animals were found frequently: 177 $(20.2 \%)$ houses had dogs, $60(6.9 \%)$ had pigs and $37(4.2 \%)$ had both dogs and pigs. Most of the inhabitants had already bred pigs when living in rural areas and a hundred of the house keepers were breeding 406 pigs at the time.

During home visits, information about prior history of passed proglottids or adult tapeworm at any time of their lives were present at least in one of the 300 (34.3\%) houses. Besides, reports of previous seizures were also related at least in one of the $125(14.2 \%)$ houses.

The clinical examination was made in 1080 (32.3\%) people, 441 (40.8\%) males and 639 $(59.2 \%)$ females. Among all of them 500 $(46.3 \%)$ were born in Lagamar and 580 (53.7\%) were from the neighboring cities. The main jobs related by the people were: student, farmer, public job and housewife.

Illiteracy was reported by 267 (24.7\%) people. The habit of eating pork or derived products was a common practice for $992(91.8 \%)$ individuals. However they reported actual preference for well-cooked or fried meat specially during the last years. The intake of raw vegetables grown in the backyard was a habit for 689 (63.8\%) households.
Among individuals clinically examined, past history of taeniasis was present in 198 (18.3\%) and eggs of Taenia sp were identified in 24 $(1.3 \%)$ out of 1850 samples examined. Of note was that $103(9.5 \%)$ reported current or former episodes of seizures. These convulsions had begun recently in $39(37.9 \%)$ of them as indicated by taking anticonvulsivants at the time of the clinical examination.

When correlating the several epidemiological risk factors to taeniasis and cysticercosis, some positive associations were found (Table 1). It is remarkable the fact that previous history of taeniasis among households showed statistical significance with those with previous or current history of seizures (Table 2).

Otherwise, when correlating the risk factors individually inquired. Statistical association was only found between being originally from Lagamar or being a housewife with a previous history of taeniasis. The same facts correlated with prior history of seizures didn't show statistical significance except for those that were chronic carries of Taenia sp (Table 3).

Former individual history of taeniasis was positively associated with the presence of seizures, corroborating the results of domicile survey (Table 4). The relative risk of seizures was 2.3 between households and 1.7 among individuals clinically examined respectively.

Table 1 - Epidemiological factors associated with previous history of taeniasis and seizures in Lagamar, Minas Gerais State, Brazil, 19921993.

\begin{tabular}{lcc}
\hline Risk factors & Positive information on taeniasis & Positive information on seizures \\
\hline Breeding of swine & 0.0030 & 0.0291 \\
Poor conditions of breeding & 0.0334 & 0.0632 \\
Inadequate stool disposal & 0.0003 & 0.0006 \\
Unsuitable garbage disposal & 0.0008 & 0.1437 \\
\hline
\end{tabular}
$\mathrm{p}<0.05$

Table 2 - Correlation between previous history of taeniasis and of seizures in households, Lagamar, Minas Gerais State, Brazil, 19921993.

\begin{tabular}{|c|c|c|c|c|c|c|}
\hline \multirow{3}{*}{$\begin{array}{l}\text { People with } \\
\text { seizures }\end{array}$} & \multicolumn{4}{|c|}{ Information on taeniasis } & \multirow{2}{*}{\multicolumn{2}{|c|}{ Total }} \\
\hline & \multicolumn{2}{|c|}{ positive } & \multicolumn{2}{|c|}{ negative } & & \\
\hline & $\mathrm{n}^{\circ}$ & $\%$ & $\mathrm{n}^{\circ}$ & $\%$ & $\mathrm{n}^{\circ}$ & $\%$ \\
\hline 0 & 237 & 33.5 & 471 & 66.5 & 708 & 80.9 \\
\hline 1 & 53 & 56.4 & 41 & 43.6 & 94 & 10.7 \\
\hline 2 & 5 & 50.0 & 5 & 50.0 & 10 & 1.1 \\
\hline$\geq 3$ & 5 & 83.3 & 1 & 16.7 & 6 & 0.7 \\
\hline Unknown & 0 & 0 & 57 & 100.0 & 57 & 6.5 \\
\hline Total & 300 & 34.3 & 575 & 65.7 & 875 & 100.0 \\
\hline
\end{tabular}


Table 3 - Epidemiological factors associated with previous history of taeniasis and seizures in individuals clinically examined, Lagamar, Minas Gerais State, Brazil, 1992-1993.

\begin{tabular}{lcc}
\hline Risk factors & Positive information on taeniasis & Positive information on seizures \\
\hline Birth at Lagamar & 0.0081 & 0.3745 \\
Housewife & 0.0001 & 0.2352 \\
Ingestion of pork & 0.0224 & 0.0816 \\
Pork preparation & 0.2703 & 0.2453 \\
Consumption of raw vegetables & 0.3317 & 0.1513 \\
Mental disorders & 0.3362 & 0.3698 \\
Carriers of Taenia sp & 0.0649 & 0.0142 \\
Hygiene habits & 0.1974 & 0.3341
\end{tabular}

$p<0.05$

Table 4 - Correlation between seizures and previous history of seizures and taeniasis in individuals clinically examined, Lagamar, Minas Gerais State, Brazil, 1992-1993.

\begin{tabular}{|c|c|c|c|c|c|c|}
\hline \multirow{3}{*}{$\begin{array}{l}\text { Time of begining } \\
\text { seizures (age) }\end{array}$} & \multicolumn{4}{|c|}{ Information on taeniasis } & \multirow{2}{*}{\multicolumn{2}{|c|}{ Total }} \\
\hline & \multicolumn{2}{|c|}{ positive } & \multicolumn{2}{|c|}{ negative } & & \\
\hline & $\mathrm{n}^{0}$ & $\%$ & $\mathrm{n}^{0}$ & $\%$ & $\mathrm{n}^{0}$ & $\%$ \\
\hline$<1$ & 1 & 7.1 & 13 & 92.9 & 14 & 1.3 \\
\hline $1-4$ & 5 & 25.0 & 15 & 75.0 & 20 & 1.8 \\
\hline $5-9$ & 3 & 25.0 & 9 & 75.0 & 12 & 1.1 \\
\hline $10-14$ & 7 & 38.9 & 11 & 61.1 & 18 & 1.7 \\
\hline $15-24$ & 5 & 25.0 & 15 & 75.0 & 20 & 1.8 \\
\hline $25-34$ & 6 & 54.5 & 5 & 45.5 & 11 & 1.0 \\
\hline $35-44$ & 0 & 0 & 3 & 100.0 & 3 & 0.3 \\
\hline$>45$ & 1 & 20.0 & 4 & 80.0 & 5 & 0.5 \\
\hline No seizures & 170 & 17.4 & 807 & 82.6 & 977 & 90.5 \\
\hline Total & 198 & 18.3 & 882 & 81.7 & 1080 & 100.0 \\
\hline
\end{tabular}

$\mathrm{p}<0.05$

\section{DISCUSSION}

Although taeniasis and cysticercosis do not have the magnitude of other infectious diseases such as malaria, tuberculosis, Chagas or schistosomosis, they represent an important health public problem in undeveloped countries. Unfortunately, in these places there isn't compulsory notification or adequate reporting and their true incidence and prevalence are unknown5 162122.

The control of taeniasis and cysticercosis has been very difficult when we consider the interaction between this parasitosis and poor sanitary conditions, lack of basic education of the population, poor nutrition and breeding of pigs under primitive conditions that characterize endemic areas5 11141725.

Several epidemiological risk factors closely linked to taeniasis and cysticercosis were confirmed through this survey, similar to other papers recently published mainly by latinamerican researchers $4 \quad 7 \quad 8 \quad 12 \quad 1920$ 26. Socioeconomical status is shown in scientific literature as being one of the key conditions to acquire taeniasis and cysticercosis and to most of the infections or parasitic diseases, specially in the tropical and subtropical world. However, adequate stratification for these conditions has been rarely made. It could permit a better evaluation of this matter. This paper shows positive correlation among some risk factors that only reflect the sanitary conditions found in this place.

The information obtained in the survey, showed high prevalence of taeniasis $34.3 \%$ with positive history for during home visit and $18.3 \%$ people in the clinical examination. On the other hand, previous history of seizures were reported by $14.2 \%$ people during home visit and $9.5 \%$ people in the clinical examination.

This results were much higher than those found in the literature and contrast with the low prevalence of parasitological findings of $1.3 \%$ of Taenia $s p$. This data can be analized diferently. Either the positive answers were influencied and over estimated by the benefits offered to population such as medical assistance and hospital care. 
Or there was misunderstanding to identified the difference between Taenia, proglottids and others helminths. However it is important to consider that probably the epidemiological situation when the survey was carried out, was completely different from those faced 20 or 50 year ago. In addition, the information about proglottids or adults taenias in different times of their lives, were very embeded among them, although high variability and confussion related to the expelling time. Likewise, seizures were basically characterized by the information given by residents or the intake of anti-seizure drugs. Nevertheless, there might be a misunderstanding with other symptoms such as syncops, faints, dizzness among other causes.

Despite the finding in the survey that showed $83 \%$ of sanitary facilities, we often noticed the habit of defecating outdoors, mainly by children. This situation is the same reported by Arruda et al1 in two districts of Paraná State, Brazil. There the authors showed that $66.2 \%$ and $77 \%$ people prefer to defecate outdoors. Scenes like these are common in tropical and subtropical areas, favouring the dispertion of Taenia eggs excreted by chronic carriers and facilitating the coprophagia by swine. It can also contaminate water springs nearby as well as vegetables cultivated commonly in the backyard.

Domestical residues are collected in $40 \%$ of houses by public health services although its disposal isn't approppriate because there isn't prior treatment and it is only deposited in open air in the outskirts. The other $60 \%$ of houses deposit garbage in their own backyard or neighborhood. This circumtance favors the proliferation of rats, cockroaches and other arthropods, easing biological vector for many infectious diseases. Many years ago it was shown by Lawson and Gemmell15. Experiment that flies are a potential source of Taenia eggs dissemination.

The breeding of domestic animals is part of our own culture. Many of these animals are the only protein source for basic nutrition for people, especially in the poorest regions where the pigs are preferred because of their easy and cheap maintenance and far from any sanitary control. Thus the main epidemiological condition for intermediary reservatory of Taenia solium infestation in the nature is garanted due to the close relation with household and the conditions that facilitate the intake of human excrement by them 351114 .

A hundred (11.4\%) houses were presently breeding swine. Other recently works have shown
$33 \%$ and $49.4 \%$ of breeding swine under primitive maintenance in $94 \%$ of them 91920 . These results coincide with those detected in Lagamar City and reinforce the positive association between this fact and taeniasis, explaining the posible etiology of seizures related with cerebral cysticercosis in endemic area.

The correlation among several risk factors to taeniasis and cysticercosis when the individuals were questioned only showed positive association between prior history of taeniasis and the fact of being originally from Lagamar or being a housewife or both.

The first association is explained by the epidemiological conditions found there and specially by the existence of milk industry in the city whose excedents are thrown into the small river and are used as supplemental alimentation of swine by the breeders before reaching the river.

The positive association between housewife with taeniasis could be defined by several ways: usually, women go to the health center more often the men. Commonly they take part in the breeding of pigs, and they have close contact with them and they prepare the meals including meat. It is common practice the intake of raw meat during its preparation. Otherwise they take care of children and consequently they are exposed to stools specially during their first years. All these factors can increase the risk of acquiring taeniasis and cysticercosis by this especific populational group4 20.

The habit of eating pork and derived products is widely diffused in this area, however, there wasn't found any statistical correlation between this habit and taeniasis. It is probably derived of the high diversity in the frequency of meat consumption related by the inhabitants of Lagamar. It varied from every day once a week, once or twice a month which decreases the association power. In spite of that, pork comsumption continues to be the main epidemiological risk fact to acquire taeniasis 1114 .

Surveys like this one must be carried out in the endemic areas with the main objetive of establishing programs of prevention and control through mass treatment as it was proposed by the World Health Organization recently4.

\section{ACKNOWLEDGEMENTS}

We are very grateful with Miss Angela Azor for English revision and Mrs Regina Moreira for her assistance in preparation of the manuscript. 


\section{REFERENCES}

1. Arruda WO, Camargo NJ, Coelho RJ. Neurocysticercosis: an epidemiological survey in two small rural communities. Arquivos de Neuropsiquiatria (São Paulo) 48:419-424, 1990.

2. Bolivar Jimenez S. La cisticercosis por Cisticercus cellulosae como zoonosis. Boletin de la Oficina Sanitária Panamericana 80:403-411, 1976.

3. Cook G. Neurocysticercosis: parasitological, clinical presentation, diagnosis, and recent advances in management. Quartely Journal of Medicine. New Series 68:575-583, 1988.

4. Cruz M, Davis A, Dixon H, Pawlowski ZS, Proano J. Operational studies on the control of Taenia solium taeniasis/cysticercosis in Ecuador. Bulletin World Health Organization 67:401-407, 1989.

5. Davis A. A epidemiologia da teníase e da cisticercose. Jornal Brasileiro de Medicina 45 (supl):9-14, 1983.

6. Del Brutto O, Sotelo J. Neurocysticercosis: an update. Reviews of Infectious Diseases 10:10751087, 1988.

7. Diaz-Camacho S, Candil-Ruiz A, Uribe MB, Willms, K. Sorology as indicator of Taenia solium tapeworm infections in a rural community in Mexico. Transactions of the Royal Society of Tropical Medicine and Hygiene 84:563-566, 1990.

8. Diaz-Camacho S, Candil-Ruiz A, Suate PV, Zazueta RM, Felix MM, Lozano R, Willms K Epidemiological study and control of Taenia solium infections with Praziquantel in a rural village of Mexico. The American of Journal Tropical and Medicine Hygiene 45:522-531, 1991.

9. Diaz F, Garcia HH, Gilman RH, Gonzalez AE, Castro M, Tsang WCW, Pilcher JB, Vasquez LE, Lascano M, Carcamo C, Madico G, Miranda E. The cysticercosis working group in Peru. Epidemiology of taeniasis and cysticercosis in a Peruvian village. American Journal Epidemiology 35:875-882, 1992.

10. Dumas PM, Grunitzky K, Belo M, Dabis F, Deniau M, Bouteille B, Kassankogno Y, Catanzano G, Pestre AM. Cysticercose et Neurocysticercose enquête épidemiologique dans le nord du togo. Bulletin Sociète Pathologie Exótique 83: 263-274, 1990.

11. Flisser A. Neurocysticercosis in Mexico. Parasitology Today 4:131-136, 1988.

12. Franco SS, Hincapié MC, Mejia O, Botero D. Estudio epidemiologico de epilépsia y neurocisticercosis. Revista Universidad Industrial de Santander 14:129$141,1986$.
13. Garcia H, Martinez M, Gilman R, Herrera G, Tzang V, Pilcher J, Verastegui M, Gallo C, Porras M, Alvarado $\mathrm{M}$, Naranjo J, Miranda E. Diagnosis of cysticercosis in endemic regions. Lancet 338:549-551, 1991.

14. Gonzalez-Luarca E. Situação atual do complexo teníase humana cisticercose nas Américas. Comunicações científicas da Faculdade de Medicina Veterinária e Zootecnia da Universidade de São Paulo 8:222-226, 1984.

15. Lawson JR, Gemmell MA. The potential role of blowlies in the transmission of Taenia tapeworm eggs. Parasitolology 91:129-143, 1985.

16. Mahajan RC. Geographical distribution of human cysticercosis In: Flisser A, Willms $\mathrm{K}$, Laclete JP, Larralde C, Ridaura C, Beltron F. Cysticercosis present state of knowledge and perspectives. New York, Academic Press, p. 39-46, 1982.

17. Mateos J, Biagi F, Marques H, Kretschmer R, Schnaas G. Cisticercosis como problema de salud pública. Gaceta Médica México 103:225-250, 1972.

18. Medina MT, Rosas E, Rubio-Donnadieu F, Sotelo J. Neurocysticercosis as the main cause of late onset epilepsy in Mexico. Archives of Internal Medicine 150:325-327, 1990.

19. Sarti-Gutierrez E, Schantz PM, Lara-Aguilera R, Gomez-Dandoy H, Flisser A. Taenia solium taeniasis and cysticercosis in a Mexican village. Tropical Medicine and Parasitology 39:194-198, 1988.

20. Sarti-Gutierrez E, Schantz PM, Plancarte A, Wilson M, Gutierrez I, Lopez A, Roberts J, Flisser A. Prevalence and risk factors for Taenia solium taeniasis and cysticercosis in humans and pigs in a village in Morelos, Mexico. The American Journal of Tropical Medicine and Hygiene 84:563-566, 1990.

21. Schenone H, Ramirez R, Rojas A. Aspectos epidemiológicos de la neurocisticercosis en America Latina. Boletin Chileno de Parasitología 28:61-72, 1973.

22. Schenone H, Villaroel F, Rojas A, Ramirez R. Epidemiology of human cysticercosis in Latin American. In: Flisser A, Willms K, Laclete JP, Larralde C, Ridaura C, Betrán F. Cysticercosis present state of knowledge and perspectives. New York, Academic Press, p. 25-38, 1982.

23. Shorvon SD. Epidemiology, classification, natural history and genetics of epilepsy. Lancet 863:93-96, 1990.

24. Silva-Vergara ML, Vieira CO, Castro $\mathrm{JH}$, Micheletti LG, Otaño AS, Franquini Jr J, Cabral M, Leboreiro A, 
Marques JO, Souza WF, Costa-Cruz JM, Prata A. Achados neurológicos e laboratoriais em população de área endêmica para teníase-cisticercose, Lagamar, MG, Brasil (1992-1993). Revista do Instituto de Medicina Tropical de São Paulo 36:335342, 1994.

25. Silva-Vergara ML, Prata A, Vieira CO, Castro JH, Micheletti LG, Otaño AS, Francquini Jr J. Aspectos epidemiológicos da teníase-cisticercose em uma área endêmica em Minas Gerais, 1993. Revista da Sociedade Brasileira de Medicina Tropical 28:345349, 1995.

26. Vianna LG, Macêdo V, Costa-Cruz JM, Mello P, Souza D. Estudo soroepidemiológico da cisticercose humana em Brasília, Distrito Federal. Revista da Sociedade Brasileira Medicina Tropical 19: 149-156, 1986. 